ARTIGO

\title{
EXAMINING OFFICERS’ READINESS FOR FOREIGN LANGUAGE INTERCOURSE IN INTERNATIONAL OPERATIONS
}

\author{
EXAMEN DE LA PREPARACIÓN DE LOS FUNCIONARIOS PARA INTERCURSOS EN \\ LENGUA EXTRANJERA EN OPERACIONES INTERNACIONALES
}

\section{ESTUDO DA PRONTIDÃO DE OFICIAIS PARA INTERAÇÃO DE LÍNGUA ESTRANGEIRA EM OPERAÇÕES INTERNACIONAIS}

\section{Yuliia Nenko \\ Universidade Nacional de Defesa Civil - Ucrânia}

Viktoriia Yaryhina

Universidade Nacional de Assuntos Internos de Kharkiv - Ucrânia

Valentyn Vorona

Universidade Nacional Cherkasy nomeado após Bohdan Khmelnytskyi - Ucrânia

\begin{abstract}
With the increase in the number of multinational peacekeeping, antiterrorist, search and rescue operations, it is significant for faculty members to understand the essence and structure of an officer's readiness for foreign language professional intercourse. In this study, we examine Ukrainian cadets' (future officers') perceptions on importance of the studied phenomena and personality traits necessary for effective foreign language professional intercourse. Analysis of theoretical and practical foundations of an officers' readiness for foreign language professional intercourse has been carried out. The motivational-emotional, cognitive-conceptual and functional criteria, their indicators and characteristics of the levels of its formation (initial, medium and sufficient) are specified. The total number of participants involved through questionnaires and interviews is $\mathbf{5 2 4}$ persons. The obtained data were subjected to statistical analysis, followed by qualitative interpretation and meaningful generalization. Recommendations for the faculty members are provided. This study has implications for both future educational decisions and potential areas of research.
\end{abstract}

Keywords: Language Training; Officer; Professional Intercourse.

Resumen: Con el aumento del número de operaciones multinacionales de mantenimiento de la paz, lucha contra el terrorismo, búsqueda y salvamento, es importante que los miembros de la facultad comprendan la esencia y la estructura de la preparación de un oficial para las relaciones profesionales en idiomas extranjeros. En este estudio, examinamos las percepciones de los cadetes ucranianos (futuros oficiales) sobre la importancia de los fenómenos estudiados y rasgos de personalidad necesarios para una relación profesional eficaz en idiomas extranjeros. Se ha realizado un análisis de los fundamentos teóricos y prácticos de la preparación de un oficial para las relaciones profesionales en idiomas extranjeros. Se especifican los criterios motivacionales-emocionales, cognitivo-conceptuales y funcionales, sus indicadores y características de los niveles de su formación (inicial, media y suficiente). 
El número total de participantes involucrados a través de cuestionarios y entrevistas es de 524 personas. Los datos obtenidos se sometieron a análisis estadístico, seguido de interpretación cualitativa y generalización significativa. Se proporcionan recomendaciones para los miembros de la facultad. Este estudio tiene implicaciones tanto para futuras decisiones educativas como para posibles áreas de investigación.

Palabras clave: Entrenamiento de lenguaje; Interacción profesional; Oficial.

Resumo: Com o aumento do número de operações multinacionais de manutenção da paz, antiterrorismo, busca e resgate, é importante que os membros do corpo docente entendam a essência e a estrutura da prontidão de um oficial para a relação profissional em língua estrangeira. Neste estudo, examinamos as percepções dos cadetes ucranianos (futuros oficiais) sobre a importância dos fenômenos estudados e traços de personalidade necessários para uma relação profissional eficaz em língua estrangeira. Foi realizada uma análise dos fundamentos teóricos e práticos da prontidão de um oficial para o intercâmbio profissional em língua estrangeira. São especificados os critérios motivacionalemocionais, cognitivo-conceituais e funcionais, seus indicadores e características dos níveis de sua formação (inicial, médio e suficiente). O número total de participantes envolvidos por meio de questionários e entrevistas é de 524 pessoas. Os dados obtidos foram submetidos à análise estatística, seguida de interpretação qualitativa e generalização significativa. Recomendações para os membros do corpo docente são fornecidas. Este estudo tem implicações tanto para futuras decisões educacionais quanto para áreas potenciais de pesquisa.

Palavras chave: Interação profissional; Officer; Treinamento em idiomas.

\section{Introduction}

Over the last decade, the nature of international operations has changed significantly. Due to the expansion of international contacts, increase of the amount of military cooperation, joint exercises and maneuvers, multinational operations for peacekeeping, antiterrorist, search and rescue operations under the aegis of NATO (ARISTARKHOVA, 2019), integration of armies in multinational and multicultural coalition forces (FEBBRARO; MCKEE; RIEDEL, 2008; STEWART; CLARKE; GOILLAU; VERRALL; WIDDOWSON, 2004). Non-technical interoperability in multinational forces.) there is an evident need in military specialists who are ready to adequately interact with representatives of diverse cultural communities. The widespread agreement that effective strategic communications represent a significant part of complex peace operations (WILLIAMS, 2018) dictates the orientation of the academic policy of higher military schools on convergence of military-professional, socio-cultural and language training.

Understandably, the need for reliable communication is exponentially more crucial in crisis and conflict situations than peacekeepers deal with on a daily basis (SCHARP, 2018). In order to properly perform the tasks of such missions, it is important for servicemen to be able to work in a multinational team, since the main task of all commanders, staff officers and chiefs 
is to correctly perform the tasks and commands, "coordinate the teamwork, transform the decisions of the higher ranks into commands to subordinate" (PATEŞAN; ZECHIA, 2018), communicate effectively with their foreign counterparts or build relationships with the local populations and improve the success of their deployment (CHAUVOT, 2010), etc. The officers' readiness for foreign language professional intercourse in international peacekeeping, antiterrorist, search and rescue operations will contribute to the expansion of their socio-cultural space, understanding the importance of their place in it; their ability to adequately handle the situation during professional cooperation in international peacekeeping, antiterrorist, search and rescue operations. Finally, effective professional intercourse "can be the decisive factor for the life of the officer himself, his personnel, and their ability to succeed in operations of great importance" (HOLTH; BOE, 2017).

However, "command language programs in the garrisons are not contributing much in terms of availability and efficiency or skills sustainment" (OUTZEN, 2012) and may lead to "lost tactical opportunities, garbled intelligence, frustrated negotiations and damaged partnerships" (OUTZEN, 2012).

All that acknowledged that "within the context of international cooperation that now exists across borders" (CHAUVOT, 2010), the need to train future officers for foreign language professional intercourse in international peacekeeping, antiterrorist, search and rescue operations is underscored as one of the most effective tools available for the promotion and maintenance of international peace and security (CUTILLO, 2013; INTRODUCTION TO UN PRE-DEPLOYMENT TRAINING STANDARDS FOR STAFF OFFICERS, 2011; SECURITY COUNCIL, 2019).

Given this, the formation of readiness for foreign language professional intercourse in international operations for peacekeeping, antiterrorist, search and rescue operations is a core problem that requires rapid solution at the theoretical and practical levels.

Aims and tasks. The purpose of the present survey is to carry out the analysis of theoretical and practical foundations of an officers' readiness for foreign language professional intercourse in international peacekeeping, antiterrorist, search and rescue operations.

\section{Methods}

\section{Sampling Procedure}

The Questionnaire with the invitation to participate was distributed within 350 final year undergraduate cadets and students of intensive language training courses of three major Ukrainian higher education institutions that train future officers: National University of Civil 
Defence of Ukraine, Hetman Petro Sahaidachnyi National Army Academy and Kharkiv National University of Internal Affairs. The invitation to participate was sent to 200 staff responsible for foreign languages and special language training, 150 contract servicemen (contractors). Ultimately, the total number of participants involved through questionnaires and interviews is 524 persons: 125 officers, 295 cadets, 104 contract servicemen (contractors).

The percentage of interviewed officers with service up to 10 years was $65.6 \%$ ( 82 people), with service over 10 years $-4.4 \%$ (18 people). At the same time, most of the servicemen had more than 10 years of service, namely -85 people $(81.7 \%)$ and less than 10 years -19 people $(18.3 \%)$ respectively.

\section{Instrument}

Participants were given a paper version anonymous Questionnaire written in Ukrainian. The authors implied analysis, systematization, generalization methods to investigate the modern conceptual literature on the research issue, to distinguish the criteria and indicators an officer's readiness for foreign language professional intercourse in international peacekeeping, antiterrorist, search and rescue operations. The results of observations, interviews and the authors' Questionnaires (Annex A) were taken into account. The interviews revealed the factors that impact on the formation of cadets' readiness for foreign language professional intercourse in international peacekeeping, antiterrorist, search and rescue operations. Considerable importance was attached to conversations and interviews with the experienced officers, which allowed to determine the components of readiness, the understanding the importance of knowledge of a foreign language for professional intercourse in international military formations.

The observations helped determine the need for specific training for professional intercourse, to examine the activity of cadets in foreign language learning, other parameters that affect the quality of the academic process and the formation of readiness for foreign language professional intercourse in international peacekeeping, antiterrorist, search and rescue operations.

The method of observation allowed determining the adaptability of future specialists in a foreign language environment, their ability to assess the situation in such an environment, the ability to work in an emotionally rich field, make professional decisions on military management, as well as features of English communication and its importance for tasks as close as possible to military operations. 


\section{Data Analytical Procedure}

The results of the study were processed by methods of mathematical and statistical data processing. Questionnaire as a method of mass data collection was conducted among officers, professor staff and cadets of universities. The obtained data were subjected to statistical analysis, followed by qualitative interpretation and meaningful generalization.

\section{Theoretical Framework}

There is a plethora studies related to multinational communication and intercultural understanding as well as peacekeeping operations (RAZAK; NIK; BAKAR; RAMLI, 2018). The language proficiency of military personnel is the subject of attention of such scholars as ARISTARKHOVA (2019), $\quad$ CHAUVOT (2010). $\quad$ MÜLLER (1981), $\quad$ NICULESCU; OBILISTEANU; DRAGOMIR (2019), PATEŞAN; ZECHIA (2018), etc. The English language proficiency ("the NATO prime language of communication" (PATEŞAN; ZECHIA, 2018) and cultural expertise are considered critical capabilities for any military participant in international missions (MÜLLER, 1981).

However, professional intercourse in international operations cannot be considered purely within the knowledge of a foreign language, since this approach levels out the dominant features of human communication, in particular:

$>\quad$ in the communicative process not only the movement of information is carried out, but its active exchange, perception and comprehension;

$>\quad$ information exchange exerts a psychological effect on a partner to alter his/her behavior; communication participants employ a conventional system of encoding and decoding;

professional intercourse involves the constant overcoming of communication barriers of both psychological and social nature.

Research on readiness for foreign language intercourse is relatively seldom carried out in military organizations, which are hierarchical and formalized (LEWINSKA, 2015).

The current research aims not to "pay lip service to the importance of foreign language capabilities on the battlefield", but to uncover the issue from the other side, broadening baseline capabilities of servicemen by making greater emphasis not on the language skills, but on their readiness for foreign language professional intercourse in international peacekeeping, antiterrorist, search and rescue operations, which has been traditionally viewed as "a niche 
meriting limited and episodic attention" (OUTZEN, 2012). The two are of course intimately related and can merely be effectively learned together (OUTZEN, 2012).

Analysis of survey- and interview-based studies of the communicative practices of military community, has revealed that one impediment of modern academic theories and practices represent the lack of a vision or understanding of the essence and structure of readiness for foreign language professional intercourse in international peacekeeping, antiterrorist, search and rescue operations. In this regard, it is coherent that attention should be directed to the criteria, indicators and characteristics of the levels of its formation.

Another impediment is the lack of strategy, methodology and capacity for the training of future officers in higher education establishments. Equally important, training institutions have shown limited interest in evaluating readiness of the trained personnel (CUTILLO, 2013) for foreign language professional intercourse in international peacekeeping, antiterrorist, search and rescue operations.

Researcher Lahodynskyy (2018) emphasizes that professional foreign language communication of military specialists incorporates a number of features that distinguish it from the communication of representatives of other professions, since it occurs under conditions of emotional stress, caused by the nature of professional tasks performed by these specialists, as well as the actual foreign language speech activity as a distinguished type of activity associated with the psychophysiological mechanisms of its receptive (listening and reading) and productive (speaking and writing) types.

It should be noted that the variety of tasks, operational and emotional tension, the need to adapt to adverse physical factors, formation of a new, unusual functional system of spatial orientation causes extreme versatility and high requirements for the psyche of an officer involved in international operations to maintain peace and security. In these conditions, successful implementation of military activities requires a harmonious combination of the personal, intellectual, physiological and physical professionally essential traits and qualities of an officer. These are: high emotional stability; stability of activity in conditions of growing fatigue; stability of activity in conditions of time shortage and/or insufficient information; selfcontrol; endurance to intense mental activity.

According to Lewinska (2015) not every military operation takes place in the combat environment and requires extreme sacrifices, however, an officer has to be on the highest possible level of motivation and emotional commitment.

It should also be emphasized that the abilities to quickly memorize visual and auditory information, accurately reproduce the information after a short visual or auditory perception, 
analyze the situation and make decisions based on visual samples, operate with specific concepts when assessing the situation, think clearly and logically in unpredictable, difficult and stressful situations, act unconventionally are also included into the catalogue of capabilities which officers should have.

\section{Findings}

Descriptive statistics on importance of an officers' readiness for foreign language professional intercourse in international peacekeeping, antiterrorist, search and rescue operations

The notable importance of the surveyed phenomenon is emphasized by the results of the evaluation of future officers' readiness for foreign language professional intercourse in international peacekeeping, antiterrorist, search and rescue operations carried out in National University of Civil Defence of Ukraine, Hetman Petro Sahaidachnyi National Army Academy and Kharkiv National University of Internal Affairs.

Students' (cadets') perceptions on importance of readiness for foreign language professional intercourse in international peacekeeping, antiterrorist, search and rescue operations

Results from the Questionnaire (Annex A) suggested that 75\% of officers and contractors and $6 \%$ of cadets have previously taken part in the antiterrorist operations and the Joint Forces Operation in Ukraine. 63 servicemen (12\%) took part in international peacekeeping or rescue operations.

We identified that $147(49.83 \%)$ respondents perceive correctly the essence of the studied notion. 125 people $(42.37 \%)$ provided answers with some errors, which can be explained by the fact that no previous training of participants has been done, and they encounter this concept for the first time.

A total of 119 people (95.2\% from the officer corps) acknowledged the intense need to develop readiness for foreign language professional intercourse in international peacekeeping, antiterrorist, search and rescue operations and the appropriate level of foreign language proficiency to perform peacekeeping tasks. The same opinion is shared by 252 cadets $(85.4 \%)$.

The surveyed officers revealed the uppermost need for the readiness for foreign language professional intercourse than the contractors and cadets. This can be explained by the fact that such officers and contractors were directly involved in international peacekeeping and security operations and practiced communication with foreign colleagues, where the language of interpersonal (private) and official communication was English. 
Most respondents intend participating in international peacekeeping and security operations - (89.69\%). 125 officers consider it necessary to develop readiness for foreign language professional intercourse in international peacekeeping, antiterrorist, search and rescue operations when learning in an educational institution, emphasizing the lack of time to adapt whilst performing the duty in international operations. 205 cadets $(70.16 \%)$ and 90 contract servicemen (86\%) (junior commanders) share the similar opinion.

Consultations among faculty staff on this issue led to the assumption that the low rate among cadets $(70 \%)$ in understanding the importance of the studied phenomenon indicates their lack of experience of military service in international military contingents.

However, 498 people (95.04\%) admitted that, in their opinion, foreign language training in higher education institutions only partially meets the urgent needs of servicemen.

Students' (cadets') perceptions on personality traits necessary for foreign language professional intercourse in international operations for peacekeeping, antiterrorist, search and rescue operations

Every professional activity requires certain eminent qualities, which are being formed, developed and improved during professional training. Consequently, a graduate of a higher education institution must have formed essential professional qualities that will change during an officer's professional activity and acquire a more superior level of development.

The conducted survey allowed singling out the basic personality traits necessary for successful participation of an officer in international operations for peacekeeping, antiterrorist, search and rescue operations. A list of character strengths and competencies was given. The participants were then requested to judge each character's strength and competency separately based on their subjective perception of the importance (BOE, et al., 2017) for foreign language professional intercourse of officers. These were in ranked divided into several blocks: management skills, intellectual, emotional and motivational, behavioral, spiritual and moral, communicative qualities and skills.

Management skills: quarterback and make decisions; regulate the activity of the unit, maintain its constant combat and moral-psychological readiness; manage the unit in both usual and extreme conditions; maintain the statutory order and discipline in the unit; adopt appropriate style of communication with subordinates in a particular situation; prevent and resolve interpersonal conflicts in the unit; determine the optimal socio-psychological distance while interacting with subordinates and commanders, ensure the necessary regulation of communication; influence subordinates, demonstrate self-confidence, combine exactness with 
granting of freedom for display of initiative and independence by personnel; establish relations based on mutual respect and trust, be friendly and tactful in relations with subordinates etc.

Intellectual qualities: mobility of knowledge; critical thinking; flexibility of thinking; intense development of general, social and verbal intelligence; general functional literacy; ability to perform normative social roles due to the successful assimilation of theoretical knowledge and practical experience in various spheres of public life (technology, economics, politics, culture); knowledge of the features of interpersonal communication; efficiency of mental processes; the ability to predict the probable development of a situation and possible consequences; knowledge of psychology and ethics of professional communication etc.

$>\quad$ Emotional and motivational qualities: positive self-esteem; leadership; activity; moderate risk appetite; desire for self-improvement; focus on the profession; exceptional subjective control; emotional stability; stress resistance; temperance; flexibility, initiative, openness, tactfulness etc.

Behavioral qualities and skills: energy; activity; initiative; flexibility of behavior; ability for team work; ability to anticipate the actions of others; ability to take into account the psychological characteristics of a communication partner; psychological tact; executive discipline, purposefulness, endurance, perseverance, courage, ability to overcome difficulties; justice and respect for human dignity, lack of irritability etc.

Spiritual and moral qualities: goodwill; tolerance; love for people; ability to empathize, mercy; demanding of himself and subordinates; responsibility; developed sense of duty; honesty; dedication, dedication to professional duty; observance of generally established moral norms and standards; independence of views; professional conscience, professional honor, professional dignity and professional justice; adherence to principles; tact; social normativeness (compliance of ethical attitudes with conventionally established behavior norms).

Communicative qualities and skills: ability for spontaneous speech; need for cooperation; ability to perceive verbal and nonverbal signs of behavior; ability to persuade people, to inspire confidence in them; ability to give clear, concise wording; ability to present thoughts coherently and logically in expanded forms; ability to convey emotions or feelings through gestures, facial expressions, voice changes, the ability to understand the subtext of speech (irony, joke, "back" thoughts); the ability to convey to the listener their thoughts and intentions; the ability to rapidly find the right tone, appropriate form of communication depending on the psychological state and personal characteristics of the interlocutor; ability to 
quickly establish contacts with unfamiliar people; ability to reasonably combine business and personal contacts with others; ability to coordinate their actions with the actions of others; knowledge of the fundamental principles of written communications.

The evaluation of English language proficiency of future military personnel was carried out in accordance with the description of the standards to be met for the NATO Standardization Agreement 6001 - STANAG 6001 (NATO, 2010). Both the receptive (reading and listening) and the productive (speaking and writing) skills were examined.

A challenging task for cadets was to quickly perform English language oral or written exercises in class. Only $14.32 \%$ of respondents were able to perform this task at a high level. We determined that $55.85 \%$ of cadets can engage in a professional conversation in English, however, the percentage of those who communicate at the elementary (beginner) level remains significantly high: $29.83 \%$.

The cadets' knowledge of the peculiarities of military, political and technical information transfer, rules of the staff culture, knowledge of abbreviations and their meanings used during radiotelephone communication, radio exchange and daily communication of participants international operations, peculiarities of professional English language communication with foreign colleagues in their area of specialization are recognized as insufficient.

The cadets experienced considerable difficulties in composing interrogative sentences on everyday work issues, comprehending the oral information, and maintaining a spontaneous conversation, which contained extended additional messages, conveying messages in a written form.

As expected, speaking and listening became the most complex types activities for $86.83 \%$ of cadets. Nonetheless, these activities best meet the needs of military personnel, who will engage in interlingual and intercultural communication in the performance of their duties in international peacekeeping and security operations.

Since almost all groups of respondents determined that an officer should be fluent in a foreign language and be able to communicate on professional topics, we invited the contractors to self-assess their level of English language proficiency, which revealed that only $20.19 \%$ of can speak English fluently on professional topics; $36.54 \%$ can communicate only on everyday topics; $41.35 \%$ obtain the required minimum knowledge, others (1.92\%) can express their opinions by means of an electronic translator.

Predominantly, the cadets exposed high motivation to participate in international peacekeeping operations, understand the need for proper training of foreign language to 
communicate with foreign colleagues, exhibit personal characteristics necessary for professional interaction and performance of tasks in conditions of emotional tension.

However, the survey revealed that teachings staff do not always implement forms and methods of personality-oriented, problem-based and interactive training, do not model various aspects of professional interaction in a foreign language environment during international peacekeeping and security operations.

$82.06 \%$ of cadets point to the insufficient use of information and computer technologies in the educative process. Respondents believe that in the age of information technology development and the transition of the Armed Forces to NATO military standards, the introduction of interactive teaching methods, role-playing and games should be significantly intensified. Respondents acknowledge the need to implement motivational methods, Internet technologies and practical situational tasks, round tables, debates, discussions, presentations in English, reading modern authentic dialogues and texts, working out colloquial clichés and terms, moving away from standard, outdated approaches to language learning.

The analysis of textbooks and learning manuals also showed that teachers do not attach due importance to the formation of future officers' readiness for foreign language professional intercourse in international peacekeeping, antiterrorist, search and rescue operations, which allows to conclude that command language programs may exist on paper, but they are not enhancing future officers' readiness for foreign language professional intercourse.

\section{Discussion}

Structure of an officer's readiness for foreign language professional intercourse

Following the scholarly literature (ARISTARKHOVA, 2019; HREBENIUK, 2019), analysis of the content and essence of professional activities to maintain peace and security allows to conclude that an officer's readiness for foreign language professional intercourse in international peacekeeping, antiterrorist, search and rescue operations can be considered as a complex personal entity, comprising professional and linguistic knowledge, skills, abilities and personal qualities necessary for interlingual, intercultural communication whilst performing professional, socially significant duties in a foreign language environment to ensure peace and security.

The basis of professional readiness to perform a socially significant professional duty of a serviceman in international peacekeeping operations is a foreign language competence (ER, 2012; MONAGHAN, 2012). Therefore, systematic, consistent and comprehensive language training is of paramount importance for the servicemen's readiness 
for foreign language professional intercourse in international peacekeeping, antiterrorist, search and rescue operations.

Generalization of diverse positions of scholars on the structure of readiness for foreign language professional intercourse, requirements of legal documents (A New Partnership Agenda. Charting A New Horizon for UN Peacekeeping, 2009; United Nations Peacekeeping Operations. Principles and Guidelines, 2008; UN Peacekeeping PDT Standards, 2011) concerning professionally significant qualities of the military specialist, results of the expert evaluation allow to interpret the structure of an officer's readiness for foreign language professional intercourse in international peacekeeping, antiterrorist, search and rescue operations as a combination of motivational-emotional, cognitive-conceptual and functional criteria.

The motivational-emotional criterion determines an officer's focus on effective foreign language professional intercourse. Positive motivation activates the processes of perception, memory and thinking, primarily determines the formation of willpower and development of professional abilities.

Emotional stability and endurance determine the ability to control one's inner state, manage negative emotions and act adequately and effectively in the unforeseen situations (TORGERSEN; STEIRO; SÆVEROT, 2013) when solving their assigned missions. They are responsible for the balance of emotional state in conditions of emotional tension and stressful situations and help to maintain optimal emotional state and mental activity of an officer. The latter considerably affects the productivity of self-regulation, provides the ability to effectively perform professional tasks in an emotionally saturated field during psychological influence.

The following indicators of the motivational-emotional criterion have been determined: stable cognitive interests in mastering effective ways of professional foreign language interaction during international peacekeeping and security operations; recognition and promotion of corporate values of a military team, focus on military service, sense of duty, responsibility, honesty, discipline, diligence;

emotional stability and endurance, ability for emotional self-regulation to maintain optimal emotional state, self-control, responsibility for one's own actions and decisions, intellectual mobility, sociability, flexibility of thinking, creativity, etc.

The cognitive-conceptual criterion refers to the knowledge of means of verbal and nonverbal communication, professional terminology (military words and phrases, acronyms, even slang) (NICULESCU; OBILISTEANU; DRAGOMIR, 2019), rules of text construction 
specific to military style and genre, features of interpersonal interaction with various categories of interlocutors, taking into account their gender, age, socio-cultural and status characteristics.

English has become an official language of NATO; therefore, it is presently the lingua franca of many ongoing multinational peace operations (MEKONNEN YIBRAH KAHSAY, 2019; SINTLER, 2011). In accordance with the international agreement STANAG 6001 on the level of foreign language proficiency of servicemen to participate in international peacekeeping and security operations, servicemen must speak English language at the level of SMR2 (NATO, 2010).

In view of this, the indicators of the cognitive-conceptual criterion comprise the following:

knowledge of features and rules of interpersonal interaction, knowledge of professional terminology and features of information transfer of military, military-political and military-technical character;

$>\quad$ tolerant attitude to other nationalities, languages, traditions, openness to the new;

$>\quad$ mastering algorithms of speech behavior in diverse challenging and demanding situations.

Importance of the functional criterion is due to the importance of dialogue in international operations to maintain peace and security. It presupposes a sufficient level of skills and abilities of constructive and effective contact interaction with the professional environment, effective use of the acquired knowledge, skills and abilities of communicative activity, mastery of modern technologies of decision-making during standard and non-standard professional situations in terms of limited time and resources, analysis of behavior strategies, etc.

In view of this, the indicators of the functional criterion are as follows:

> skills to establish and maintain contacts, capacity for teamwork;

$>\quad$ ability to resolve conflicts;

$>\quad$ ability to clearly and intelligibly convey information and instructions to subordinate personnel and civilians.

It is imperative to note that the abovementioned components and criteria cannot be considered in isolation, as they are integrative in nature and represent the conclusive result of professional training of the officers.

A level approach is taken to determine an officers' readiness for foreign language professional intercourse in international peacekeeping, antiterrorist, search and rescue operations. Level is the degree of quantitative and qualitative manifestation of various 
characteristics of readiness; the degree of expression of certain properties and qualities of personality, their compliance with the standard.

According to the logic of the study and on the basis of the selected criteria, three levels of the studied phenomenon are differentiated: initial, medium and sufficient.

Initial level. A cadet has infrequent or no interest in mastering effective ways of professional foreign language interaction during international peacekeeping and security operations. He/she is characterized by low focus on military service, unformed feelings of duty, responsibility, honesty, discipline, diligence; reduced ability for emotional self-regulation and self-control; insufficient intellectual mobility, flexibility of thinking, etc. A person is minimally aware of the features and rules of interpersonal terminology, has weak knowledge of professional terminology and features of information transfer of military, military-political and military-technical character; superficial knowledge of algorithms of speech behaviors in various situations. A cadet is sometimes intolerant of representatives of other nationalities, languages, traditions, not open to the new. He/she demonstrates fragmentary skills to establish and maintain contacts, insufficient capacity for teamwork; inability to resolve professional conflicts; weak ability to clearly and intelligibly convey information and instructions to subordinate personnel and civilians.

Intermediate level. The cadet expresses unstable interest in mastering effective ways of professional foreign language interaction during international peacekeeping and security operations. He/she is characterized by inconsistent focus on military service, sense of duty, responsibility, honesty, discipline, diligence; reveals situational manifestation of ability for emotional self-regulation and self-control; periodic intermittent flexibility of thinking and intellectual mobility. A person is sufficiently aware of the features and rules of interpersonal terminology, has unstructured knowledge of professional terminology and features of information transfer of military, military-political and military-technical character; fragmentary and unstructured knowledge of algorithms of speech behaviors in various situations. A cadet is mostly tolerant of representatives of other nationalities, languages, and traditions and open to the new. He/she demonstrates primary skills to establish and maintain contacts, capacity for teamwork; situationally shows the ability to resolve professional conflicts; sometimes faces difficulties provided that new, unconventional tasks and communicative situations arise; average ability to clearly and intelligibly convey information and instructions to subordinate personnel and civilians.

Sufficient level. A cadet manifests deep interest in mastering effective ways of professional foreign language interaction during international peacekeeping and security 
operations. He/she is characterized by constant manifestation of focus on military service, sense of duty, responsibility, honesty, discipline, diligence; highly developed ability for emotional self-regulation and self-control; considerable flexibility of thinking and intellectual mobility. A person is profoundly aware of the features and rules of interpersonal terminology, has stable, systematic knowledge of professional terminology and features of information transfer of military, military-political and military-technical character; in-depth knowledge of algorithms of speech behaviors in various situations. A cadet is always tolerant of representatives of other nationalities, languages, and traditions and open to the new. He/she demonstrates developed skills to establish and maintain contacts, capacity for teamwork; ability to resolve professional conflicts; distinguished ability to clearly and intelligibly convey information and instructions to subordinate personnel and civilians.

\section{Recommendations}

The findings of current research can eventually have impact on both academic decisions and potential areas of research; some recommendation can be designated in the paper.

1. Language training in military higher education institutions should be based on general didactic principles of teaching: principle of systematic and consistent learning, principle of conscious assimilation of knowledge, principle of activity and independence, principle of connection of learning with life. Among the specific pedagogical principles, we should emphasize the principle of specialization (targeting), principle of rigorous regulation and time limitation, principle of differentiation and optimization of the educational process.

2. It is pertinent to introduce forms and methods of personality-oriented, problembased and interactive learning into the educational process. Particular importance should be attributed to role-playing games, which, based on the potential problems of certain situational tasks, should be an effective means of acquiring knowledge, skills, abilities in a particular situation. They allow to propound and solve problems that reveal specific aspects of the activities of the servicemen; analyze the problems that focus the officer's attention on resolving problems when communicating in a foreign language, enhance the formation of language competence; improve practical knowledge and appropriate level of communication culture in a foreign language. Below are examples of communicative situations for role-playing to practice strategy and tactics of professional intercourse.

During the first informal meeting with foreign colleagues, you have to introduce yourself and explain the aim of your participation in the international operation. What side of your life (civilian or military) will you describe? Will your self-presentation differ depending on the 
formality of the event? Will you specify personal information? Will you try to draw the attention of foreign colleagues to the unique responsibilities you perform? Will you involve and encourage foreign colleagues in the conversation?

During the joint task, the representatives of the German peacekeeping contingent began to openly ridicule you because of your ignorance of the German language and the insufficient knowledge of English. What are your actions? Will you start a "massacre" of those who insult you?

You have been appointed commander of a new multinational unit, which will carry out a number of important peacekeeping tasks for some time. One of the tasks of the commander is to create a favorable atmosphere and mutual trust in the team, support the initiative and maintain mutual understanding with foreign colleagues: how will you achieve this? What leadership style will best suit the role of commander?

While patrolling the Serb-Albanian village, a representative of the Serbian side approaches you and shows you a cross-shaped ornament and calls you to start a fight: "We are brothers with you, Ukrainians, we are Orthodox, and Albanians are Muslims, we will defeat them together!" What are your actions? Will you take part in the conflict situation that is beginning? Will you follow the UN rules on tolerance of the world's religions? Will you defend "yours"?

3. To develop the readiness of servicemen for future professional interaction, information and computer technologies should be used, which allow improving skills of receiving and transmitting information in a limited time, effective English language communication skills. Training, information search and control programs allow to expand the possibilities of providing educational information and to diversify the learning activities. It is advisable to utilize open learning platforms, such as Ed era, Edmodo, Eliademy, Moodle, OpenedX, Prometheus, exclusively designed websites (Quizlet, Kahoot, Mentimeter etc.), applications for constructing mental maps like Mindomo, Spinscape, Comapping, Mind42, Text2MindMap, VivaMind, SpiderScribe, blogs, social networks and YouTube.

4. During professional training, attention should be focused on the fact that future officers not only acquire knowledge, but first of all, work in conditions that simulate future professional activity. To form behavior patterns and skills that are necessary for future professional cooperation in maintaining peace and security, it is necessary to acquaint cadets with the features of their future professional activity. In view of this, it is advisable to model various situational tasks, which allow cadets to study aspects related to cultural tradition, social factors and specifics of language of a particular cultural and linguistic community - language 
barriers, features of nonverbal communication, perception analysis, stereotypes, circumstances of time and place, features of information movement.

5. Extensive attention should be directed to thematically selected texts that relate to modern terminology for armaments and equipment of forces (countries) involved in international operations, help cadets to master the terminological minimum for professional communication in a foreign language, explain the peculiarities of the transfer of information of military, military-political and military-technical nature, as well as to learn the abbreviations and their meanings that are used when conducting radiotelephone communication, radio exchange and in the daily communication of participants in international operations. A number of tasks should relate to the rules of drawing up and maintaining documentation in English in accordance with the staff culture. Performing such tasks, cadets learn to obtain the necessary information in English in a shortage of time, draw conclusions, select and find specific material in more complex texts related to their own professional field of activity, to transform the content of the read or listened English-language source to a plan, annotation, generally enriching their vocabulary, improving fluency in English.

It is equally important for cadets to study the culture of English language communication with foreign colleagues while participating in international operations, as well as the language culture, history and realities of countries and organizations where English is the state or working language. Particular attention should be directed to the knowledge and skills needed to understand a variety of well-defined topics: current, past and future events, personal and family news, personal and public affairs, everyday work issues that describe people, places or things.

6. The results of our study prove the inefficiency of implication of traditional methods of professional training of cadets in terms of building their readiness for foreign language professional intercourse in international peacekeeping, antiterrorist, search and rescue operations; in addition to obtaining the necessary information about the types, forms and methods of professional intercourse in typical and atypical situations, cadets must acquire practical skills. The lack of these skills leads to the fact that a future officer, who receives high marks in theory, is not ready for professional communication in a particular communication situation.

7. The insufficiency of practical skills leads to the fact that a cadet who receives excellent marks while mastering the theory, is not ready for professional intercourse in a particular communication situation. We recognize the application of interactive teaching methods imperative for effective training of future officers. Interactive teaching methods are characterized by superior motivation and emotionalism, direct feedback between the 
participants of the educational process, their intense communicative and mental activity. Interactive teaching methods are those tools of the educational process that contribute to the formation of skills and abilities (primarily - communication), mandatory for further professional activities; they intensify the cadets' enthusiasm, independence and imagination, ability to cooperate, boost training activities, eliminate the natural stiffness, allow to learn the material at a natural pace, and are effective in the context of individualization of learning.

Currently there is a vast arsenal of interactive learning methods: dialogue, discussion, role-playing games, communicative training, and work in pairs, microgroups, "Microphone", "Brainstorming", "Situation Analysis", "Rotating Triples", "Carousel", debates and more. Traditional lectures can be partially replaced by lectures based on an interactive approach, in particular: "Lectures-conferences", "Lectures-consultations" etc.

\section{Conclusions}

The results of this study are essential as they provide information to faculty staff on the importance of an officer's readiness for foreign language professional intercourse in international peacekeeping, antiterrorist, search and rescue operations. The latter is understood by the authors as a complex personal entity, comprising professional and linguistic knowledge, skills, abilities and personal qualities necessary for interlingual, intercultural communication whilst performing professional, socially significant duties in a foreign language environment to ensure peace and security. It can be assessed by motivational-emotional, cognitive-conceptual and functional criteria. The formation of readiness for foreign language professional intercourse can be manifested at the initial, intermediate and sufficient levels. Recommendations, developed on the basis of the conducted survey, are crucial for the teaching staff to be implied in the educational process, design of courses and further academic research.

\section{REFERENCES}

A New Partnership Agenda. Charting A New Horizon for UN Peacekeeping. (2009). Department of Peacekeeping Operations and Department of Field Support. NY. Available at: https://peacekeeping.un.org/sites/default/files/newhorizon_0.pdf

ARISTARKHOVA, M. S. (2019). Modern Approaches to Development to Foreign Language Communicative Competence of Military Lecturers. Science and Education a New

Dimension. Pedagogy and Psychology, VII (82), Issue 202, pp.7-10. DOI: https://doi.org/10.31174/SEND-PP2019-202VII82-01 
BOE, Ole; BANG, Henning. (2017). The Big 12: The Most Important Character Strengths for Military Officers. Athens Journal of Social Sciences, Volume 4, Issue 2, pp. 161-174. DOI: https://doi.org/10.30958/ajss.4-2-4

CHAUVOT, Pascale. (2010). The Benefits of Language Training for Military Personnel. Communicaid. Available at: https://www.communicaid.com/business-languagecourses/blog/the-benefits-of-language-training-for-the-military-personnel/

CUTILLO, Alberto. (2013). Deploying the Best: Enhancing Training for United Nations Peacekeepers. Providing for Peacekeeping, 5. New York: International Peace Institute.

ER, Mustafa. (2012). The role of foreign language in the success of global military operations and English as a global lingua franca. International Journal of Social Sciences and Humanity Studies, 4(1), pp. 279-286. Available at: https://www.sobiad.org/eJOURNALS/ journal_IJSS/arhieves/2012_1/mustafa_er.pdf

FEBBRARO, Angela R.; MCKEE, Brian; RIEDEL, Sharon L. (2008). Multinational military operations and intercultural factors. North Atlantic Treaty Organization, Research and Technology Organization: Neuilly-sur-Seine Cedex, France

HREBENIUK, Larysa. (2019). Foreign Language Competence as Psychological and Pedagogical Problem in the Structure of Nowadays Military Education. Research and Innovation: Collection of scientific articles. Fadette editions, Namur, Belgium, pp.111-115. Available at: http://conferencii.com/files/archive/2019-03.pdf

HOLTH, Torill; BOE, Ole. (2017). Enhancing the Leadership Communication Skills of Norwegian Military Officers. Arts Social Sciences Journal, 8: 250. DOI: https://doi.org/10.4172/2151-6200.1000250

Introduction to UN Pre-deployment Training Standards for Staff Officers. (2011). Specialized Training Materials for Staff Officers. 1st Edition. Available at: http://biblioteca.f59.com.br/documentos/STM\%20for\%20Military\%20Staff\%20Officers\%20 Full.pdf

LAHODYNSKYY, Oleksandr. (2018). Inshomovna pidhotovka fakhivtsiv ekstremalnykh vydiv diyalnosti: psykholohichnyy vymir [Foreign language training of extreme specialists' activities: psychological dimension]. Strategies of intercultural communication in language education of modern universities, pp.38-243. Available at: https://ir.kneu.edu.ua:443/handle/2010/25128 [in Ukrainian].

LEWINSKA, Monika. (2015). The Role of Communication in Military Leadership. Journal of Corporate Responsibility, Vol. 2, Issue 1, pp.37-49. DOI: http://dx.doi.org/10.12775/JCRL.2015.003 
MEKONNEN, Yibrah Kahsay. (2019). The Importance of English Communication Skills for Ethiopian Military Observers and Police Officers in International Peacekeeping Missions. Communication and Linguistics Studies, 4(4), pp.99-107. Available at: http://www.sciencepublishinggroup.com/journal/paperinfo?journalid=357\&doi=10.11648/j.cl s.20180404.11

MONAGHAN, Richard. (2012). Language and Interoperability in NATO: The Bureau for International Language Co-ordination (BILC). Canadian Military Journal, 13, pp.23-32. Available at: http://freejournal.umm.ac.id/files/file/Language\%20and\%20Interoperabililty\%20in\%20NATO\%20The $\% 20$ Bureau\%20for\%20International\%20Language\%20Co-ordination\%20(BILC).pdf

MÜLLER, Kurt E. (1981). On the Military Significance of Language Competence. The Modern Language Journal, 65(4), pp. 361-370. DOI: https://doi.org/10.2307/327375

NATO. (2010). Language Proficiency Levels. STANAG 6001 NTG (Edition 4). Brussels: NATO Standardization Agency Available at: http://www.bilc.forces.gc.ca/stanag/index-eng.asp

NICULESCU, Brânduşa-Oana; OBILISTEANU, Georgeta; DRAGOMIR, Isabela Anda. (2019). Contribution of Foreign Languages to Building the Professional Career of the Land Forces Academy Cadets. Land Forces Academy Review, 3(95), Vol. XXIV, pp. 213-219. DOI: https://doi.org/10.2478/raft-2019-0025

OUTZEN, Richard. (2012). Language, Culture, and Army Culture: Failing Transformation. Wmall Wars Journal. Available at: https://smallwarsjournal.com/jrnl/art/language-culture-and-army-culture-failingtransformation

PATEŞAN, Marioara; ZECHIA, Dana. (2018). Foreign Language Education in the Military. International conference Knowledge-based organization, 24(2), pp.351-355. DOI: https://doi.org/10.1515/kbo-2018-0114

RAZAK, Najjah Salwa Abd; NIK, Ramli H; BAKAR, Kaseh Abu; RAMLI, Mhd Faizal Mhd. (2018). Language, Communication and Intercultural Understanding in Peacekeeping Operations. International Journal of West Asian Studies, 10(8), pp.85-95. DOI: https://doi.org/10.22583/ijwas.2018.10.01.08

Security Council. (2019). Security Council Issues Presidential Statement Underscoring Key Role of Peacekeeping in Promoting, Maintaining International Peace. 8521ST Meeting. United Nations Meetings Coverage and Press Releases. Available at: https://www.un.org/press/en/2019/sc13800.doc.htm 
SCHARP, Mats Pellbäck. (2018). Mission-critical communication for UN peacekeepers. Ericsson Blog. Available at: https://www.ericsson.com/en/blog/2018/10/mission-criticalcommunication-for-un-peacekeepers

SINTLER, Peter. (2011). English as Lingua Franca in military meetings within a Multinational Peacekeeping Mission. Diplomarbeit, University of Vienna. DOI: https://doi.org/10.25365/thesis.14954.

STEWART, Keith G.; CLARKE, H.; GOILlAU, P.; VERRALL, N.; WIDDOWSON, M. (2004). Non-technical interoperability in multinational forces. Proceedings of the 9th International Command and Control Research and Technology Symposium, 14-16 September 2004. Copenhagen, Denmark. Available at: http://dodccrp.org/events/10th_ICCRTS/CD/papers/298.pdf

TORGERSEN, Glenn Egil; STEIRO, Trygve J.; SÆVEROT, Herner. (2013), Strategic education management: Outlines for a didactic planning model for exercises and training of the unexpected in high risk organizations. Proceedings of the 22ndSRA E Conference, Trondheim, Norway, June 17-19, 2013. Available at: https://silo.tips/download/strategiceducation-management-outlines-for-a-didactic-planning-model-for-exerci

United Nations Peacekeeping Operations. Principles and Guidelines ("The Capstone Doctrine"). (2008). United Nations Secretariat. One UN Plaza, New York, NY 10017. Available at: https://www.un.org/ruleoflaw/files/Capstone_Doctrine_ENG.pdf

UN Peacekeeping PDT Standards. Specialized Training Material for Staff Officers. (2011). $1 \mathrm{st}$ Edition. Available at: http://biblioteca.f59.com.br/documentos/STM\%20for\%20Military\%20Staff\%20Officers\%20 Full.pdf

WILLIAMS, Paul D. (2018). Strategic Communications for Peace Operations: The African Union's Information War Against al-Shabaab. Stability: International Journal of Security \& Development, 7(1): 3, pp. 1-17, DOI: https://doi.org/10.5334/sta.606

\section{ABOUT THE AUTHORS:}

\section{Yuliia Nenko}

Doctor of Education, Professor; National University of Civil Defence of Ukraine - Ukraine; Head of Foreign Languages Department. Julia18016@ukr.net

iD https://orcid.org/0000-0001-7768-9668 
Viktoriia Yaryhina

Candidate of Philological Sciences; Kharkiv National University of Internal Affairs - Ukraine; Lecturer at the Department of Foreign Languages. vikula801@ gmail.com

(iD) https://orcid.org/0000-0001-7768-9668

\section{Valentyn Vorona}

PhD Student; Cherkasy National University named after Bohdan Khmelnytskyi - Ukraine. crowvalentin@gmail.com

(iD) https://orcid.org/0000-0002-8891-8662

\section{Annex A}

Questionnaire to determine the understanding of the importance of an officer's readiness for foreign language professional intercourse in international peacekeeping, anti-terrorist, search and rescue operations

1. Do you have experience of participating in international peacekeeping, antiterrorist, search and rescue operations?
a. yes
b. no

2. How did you know that servicemen can take part in international peacekeeping, anti-terrorist, search and rescue operations?
a. in the classroom
b. teachers shared their own experiences
c. from the Internet
d. from family members
e. other

3. Would you like to take part in international peacekeeping, anti-terrorist, search and rescue operations?
a. yes
b. no
c. didn't think about it

4. Do you think that foreign language training is part of the compulsory training of a serviceman?
a. yes
b. no
c. partially
d. other, please, specify

5. Is readiness for foreign language professional intercourse important in the activities of an officer involved in international operations?
a. yes
b. no
c. I don't know
d. other, pleases, specify

6. What difficulties did you face during the international operations? Please, specify. 
7. Is the foreign language training at your higher education institution sufficient for the officer to further participate in international operations?
a. yes
b. no
c. partially
d. other, please, specify

8. Please, provide a definition of "readiness for professional foreign language intercourse". Your personal vision, interpretation (brief, no more than 5 lines).

9. Is it necessary to develop an officer's readiness for professional foreign language intercourse during international peacekeeping, anti-terrorist, search and rescue operations while studying in a higher education institution?
a. yes
b. no
c. other, please, specify
Justify your point of view. 